\title{
キャビティエンハンスト 吸収分光法によるプラズマトーチ気流診断*1 Diagnostics of Plasma Torch Flow by Cavity Enhanced Absorption Spectroscopy
}

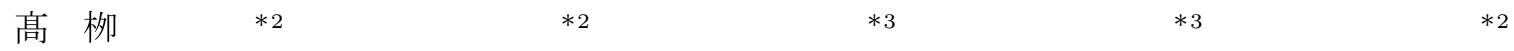 \\ Hiroki Takayanagi, Makoto Matsui, Kimiya Komurasaki, Hideaki Ochimizu and Yoshihiro Arakawa
}

Key Words : Laser Diagnostics, Plasma Flow, High Sensitive Spectroscopy, Cavity Enhanced Absorption Spectroscopy

\begin{abstract}
The cavity enhanced absorption spectroscopy using a tunable diode laser was applied to plasma torch diagnostics. Using cavity mirrors with $99.95 \%$ reflectance, the sensitivity was successfully enhanced by three orders of magnitude compared with the conventional single-pass laser absorption spectroscopy. With a $0.6 \mathrm{~m}$ distance cavity, the spatial resolution of less than $1 \mathrm{~mm}$ was achieved. The deviation of deduced temperature was below $5 \%$ when ten profiles were averaged. Total amount of data acquisition needed for a given plume section was estimated at $100 \mathrm{M}$ Sample. The torch plume was found in nonequilibrium electronic excitation state.
\end{abstract}

記 号 の 説 明

$$
\begin{aligned}
& A_{j i}: \text { アインシュタインの } A \text { 係数 } \\
& c: \text { 光速 } \\
& d: \text { ファブリ・ペロー共振器の共振長 } \\
& d_{0}: \text { 測定媒体の吸収長 } \\
& d_{\text {CEAS }}: \text { CEAS での有効吸収長 } \\
& f: \text { レンズの焦点距離 } \\
& g: \text { 統計重率 } \\
& h: \text { プランク定数 } \\
& i, j: \text { 吸収準位および励起準位 } \\
& I_{0}: \text { 吸収がないときの透過光強度 } \\
& I_{\text {S_inhomo }} \text { : 不均一広がりのレーザー飽和強度 } \\
& I_{\mathrm{t}}: \text { 透過光強度 } \\
& K: \text { 積分吸収係数 } \\
& k: \text { 吸収係数 } \\
& k_{\mathrm{B}}: \text { ボルツマン定数 } \\
& M_{\mathrm{A}} \text { : 原子質量 } \\
& N_{i}: \text { 吸収準位の原子数密度 } \\
& Q_{j i}: \text { 消光レート } \\
& R: \text { 高反射ミラーの反射率 } \\
& T_{\mathrm{tr}}: \text { 並進温度 } \\
& T_{\mathrm{pop}}: \text { ポピュレーション温度 } \\
& w_{0}: \text { 回折限界ビームのウェスト径 } \\
& z: \text { プラズマトーチ出口からの距離 } \\
& \lambda: \text { レーザー光波長 } \\
& \nu: \text { レーザー光周波数 }
\end{aligned}
$$

*1 C 2007 日本航空宇宙学会

平成 18 年 10 月 19 日原稿受理

*2 東京大学大学院工学系研究科

*3 東京大学大学院新領域創成科学研究科

$$
\begin{gathered}
\nu_{0}: \text { 吸収中心周波数 } \\
\Delta \nu_{\mathrm{D}}: \text { ドップラー幅 } \\
\Delta \nu_{\mathrm{L}}: \text { ローレンツ幅 }
\end{gathered}
$$$$
\text { 1. は じめに }
$$

宇宙往還機などの熱防護システム (Thermal Protection System) の開発において, 大気圏への突入環境を模擬する ために樣々なプラズマ風洞が用いられている1) . しかしな がらプラズマ風洞によって生成される気流は熱化学的に非 平衡であるため, 兴の化学組成やエンタルピーを正確に測 定することはTPS 開発上非常に重要であり，また非平衡 流流体力学計算コードの妥当性の検証にも役立つ.

我々はレーザー吸収分光法 (Laser Absorption Spectroscopy，LAS) を用いて，プラズマ風洞により生成され たアルゴン酸素混合気流や純酸素気流中の酸素原子の吸収 プロファイル $\left(777.19 \mathrm{~nm}, 3 \mathrm{~s}^{5} \mathrm{~S} \rightarrow 3 \mathrm{p}^{5} \mathrm{P}\right)$ を得ることで気 流中の数密度分布, 並進温度分布を測定してきた ${ }^{2,3)}$. しか しながら, 空気流や空気模擬ガス流においては, 測定が困 難であった . 現在世界最大級のアーク風洞 (IHG, NASA Ames）においても気流中の吸収プロファイルを検出するこ とはできていない4) . 第 1 図に熱化学平衡計算から求めた 雾囲気圧力 $30 \mathrm{~Pa}$ での純酸素流, アルゴン酸素流, 窒素酸 素流におけるエンタルピーと温度の関係を示す . 純酸素流， アルゴン酸素流と比較して, 室素酸素流においては室素の 解離に多くのエネルギーが費やされ気流の温度が上がらな いため, 結果として吸収対象である酸素原子の吸収準位粒 子の数密度が低くなることがわかる.

近年, 高感度 LAS としてキャビティリングダウン分光法 (Cavity Ring Down Spectroscopy, CRDS) が幅広く用 いられている ${ }^{5)}$. CRDS は 2 枚の高反射ミラーで形成され 


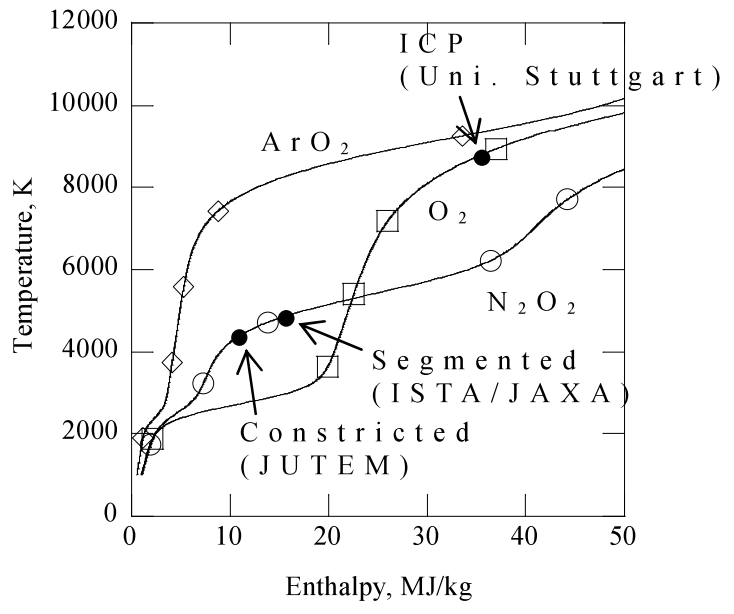

第 1 図＼cjkstart熱化学平衡計算から求めた純酸素流, アルゴン酸素流, 窒素酸 素流におけるエンタルピーと温度の関係 (雾囲気圧力 $30 \mathrm{~Pa}$ )

た共振器内に測定対象を置き, 共振器を透過するパルスレー ザーの減衰時間から吸収係数を測定する手法であり, 従来 のLAS に比べ感度を飛躍的に向上させることができる．し かしながら, 波長可変半導体レーザーを用いると気流透過 光は $\mathrm{nW}$ 以下となるため, プラズマ風洞のように強い発光 を伴う対象の場合， S/N 比が悪くなってしまうことが危惧 される .一方, 連続発振レーザー光を共振させるキャビティ エンハンスト吸収分光法 ${ }^{6)}$ (Cavity Enhanced Absorption Spectroscopy , CEAS) は CRDS と比較して感度が同程度 でありながら, 透過光強度は遥かに大きいため, プラズマ 風洞に適用しても高い $\mathrm{S} / \mathrm{N}$ 比が期待できる.

CEAS をプラズマ風洞の気流診断に適用するためには， 測定精度に加えて, 高い空間分解能と測定時間の短さが要 求される. 従来用いられてきたマルチパス型吸収分光法7) はシングルパス LAS に比べて空間分解能が悪く，アーベ ル変換によりプラズマ風洞気流の温度分布を求めることは 難しい．弚こで測定領域でのレーザー径をできるだけ絞る 必要がある．また，一般的には CEAS は 100〜1000 回の プロファイルを平均するため ${ }^{8,9)}$, 取得するデータ量が多く なり，測定時間がかかる.しかしながら MW 級プラズマ風 洞は, 安定な作動時間が 10〜20 分程度に限られるため ${ }^{10)}$, その時間内に計測できなければならない．

そこで本研究において CEAS において十分な測定精度， 空間分解能が得られるかを検証し, また, 平均する掃引回 数と測定誤差の関係を実験的に調べた．一般にプラズマ風 洞気流は減圧チャンバ内で共振器を組む必要があるが, こ こでは共振器のアライメントが容易な大気圧プラズマトー チを用いてプラズマ風洞を模擬した .

\section{2. 測 定 原 理}

2.1 レーザー吸収分光法 吸収係数 $k$, 長さ $d_{0}$ の一樣 な物質を通過するレーザー強度 $I_{\mathrm{t}}$ は Beer-Lambert の式 により次のように関係付けられる .

$$
I_{\mathrm{t}}=I_{0} \exp \left(-k d_{0}\right)
$$

また $k$ は $\nu$ 関数であり，以下のフォークト関数で表され る11).

$$
\begin{aligned}
& k(\nu)=K \frac{2}{\Delta \nu_{\mathrm{D}}} \sqrt{\frac{\ln 2}{\pi}} \frac{y}{\pi} \int_{-\infty}^{\infty} \frac{\exp \left(-t^{2}\right)}{y^{2}+(x-t)^{2}} \mathrm{~d} t \\
& x=\left(\nu-\nu_{0}\right) \sqrt{\ln 2} / \Delta \nu_{\mathrm{D}} \\
& y=\Delta \nu_{\mathrm{L}} \sqrt{\ln 2} / \Delta \nu_{\mathrm{D}}
\end{aligned}
$$

吸収プロファイルを $(2)$ 式でフィッティングさせることに より $K, \Delta \nu_{\mathrm{D}}$ および $\Delta \nu_{\mathrm{L}}$ を求める .さらに以下の式を 用いて $\Delta \nu_{\mathrm{D}}$ から並進温度, $K$ から吸収準位の数密度を求 めることができる .

$$
\begin{aligned}
& \Delta \nu_{\mathrm{D}}=\frac{2 \nu_{0} \sqrt{\ln 2}}{c} \sqrt{\frac{2 k_{\mathrm{B}} T_{\mathrm{tr}}}{M_{\mathrm{A}}}} \\
& K=\frac{\lambda^{2}}{8 \pi} \frac{g_{j}}{g_{i}} A_{j i} N_{i}
\end{aligned}
$$

$\Delta \nu_{\mathrm{L}}$ は一般に複合要因から成り立っており複雑ではあるが， プラズマ条件によっては電子密度等を推定することができ る12).

2.2 キャビティエンハンスト吸収分光法 CEASでは 測定対象の両端に 2 枚の高反射ミラーを平行に設置して Fabry-Perot 共振器を形成する . 共振長を固定すると , 共 振条件を満たすレーザー光のみか共振器を透過するため, 光 の共振間隔よりも微細なプロファイルを測定することはで きない. 本研究では対象とする大気圧プラズマの吸収線の 広がりを考慮し， $d=0.6 \mathrm{~m}$ （共振間隔 $250 \mathrm{MHz}$ ）とした。

CEAS における吸光度は, シングルパス LAS での吸光 度 $k d_{0}$ の関数であり，次式で表される ${ }^{6)}$.

$$
1-\exp \left(-k d_{\mathrm{CEAS}}\right)=\frac{\Delta I_{\mathrm{t}}}{I_{0}}=\frac{R\left\{1-\exp \left(-k d_{0}\right)\right\}}{1-R \cdot \exp \left(-k d_{0}\right)}
$$

$k d_{0} \ll 1$ の場合，(5) 式は次式のように近似できる .

$$
k d_{\mathrm{CEAS}} \approx-\ln \left(\frac{1-R}{1-R+R \cdot k d_{0}}\right)
$$

また, 吸光度がさらに小さく $R k d_{0} /(1-R) \ll 1$ の場合に は,さらに近似でき，

$$
k d_{\mathrm{CEAS}} \approx \frac{R}{1-R} k d_{0}
$$

となる

\section{3. 実 験 装 置}

第 2 図に CEAS 計測システムの概略図を示す. 本シス テムでは波長可変レーザー発振器として外部共振器付半導 体レーザー (DMD845，EOSI 社製) を用いた .レーザー 周波数の変調幅は $842 \mathrm{~nm}$ を中心に $25 \mathrm{GHz}$ 程度である． 共振器用ミラーとして曲率半径 $1 \mathrm{~m}$ の 2 枚の凹面ミラー ( $R=99.95 \%$, Layertec 社製) を用いた . 共振長を $0.6 \mathrm{~m}$

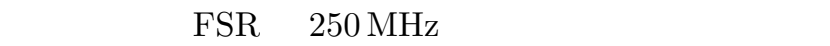


持つ 2 枚の凹面ミラーで共振器を形成したときの共振器 中央における回折限界ビームのウェスト径は解析的に求め ることができ ${ }^{13)}$, 現在の系では $w_{0}=350 \mu \mathrm{m}$ である . 图 中のアイソレータ (中心波長 $800 \mathrm{~nm}$, ISOWAVE 社製) は反射光が半導体レーザー素子に戻るのを防ぐために挿入 し，エタロン (共振間隔 $0.75 \mathrm{GHz}$ ，ネオアーク社製）は 波長掃引時の波長計として用いた .また，レーザー発振用 の外部共振器と CEAS 計測用共振器のマッチング率を向 上させるため, 2 枚のレンズ $(f=25 \mathrm{~mm}, 50 \mathrm{~mm})$ と $\phi=35 \mu \mathrm{m}$ のアイリスによる空間フィルターとマッチン グ用レンズ $(f=0.5 \mathrm{~m})$ を用いた . アルゴンの吸収波長 $\left(842.46 \mathrm{~nm}, 4 \mathrm{~s}^{2}[3 / 2] \rightarrow 4 \mathrm{p}^{2}[5 / 2] ; 4 \mathrm{~s}^{2}[3 / 2]\right.$ は $106.7 \mathrm{~nm}$ の発光を伴って基底準位に脱励起) を知るために吸収波長参 照セルとしてアルゴンガスグロー放電管 $(0.6 \mathrm{~W} ， 0.5$ Torr $)$ を用いた . プラズマからの発光を除去するためにバンドパ スフィルタ (中心波長 $840 \mathrm{~nm}$, 半值全幅 $10 \mathrm{~nm}$, ソーラ ボ社製) を通過させた後, 光電子倍増管 (H8249-102, 浜 松ホトニクス社製) で検出した .プラズマトーチの出口径 は $\phi=2 \mathrm{~mm}$ であり，作動条件は投入電力 $750 \mathrm{~W}(15 \mathrm{~V}$, $50 \mathrm{~A})$ ，体積流量はアルゴンガス $2.3 \mathrm{slm}$, 背圧は大気圧で ある. 第 3 図にプラズマトーチ作動時のプルーム写真を示 す.プルームは出口から $50 \mathrm{~mm}$ 程度までほぼ出口径に等し い径を保っている.

\section{4. 実験結果および考察}

4.1 空間分解能 共振器中央部でのビームスポット径 は， 入射光のビーム品質やアライメント，モードマッチン

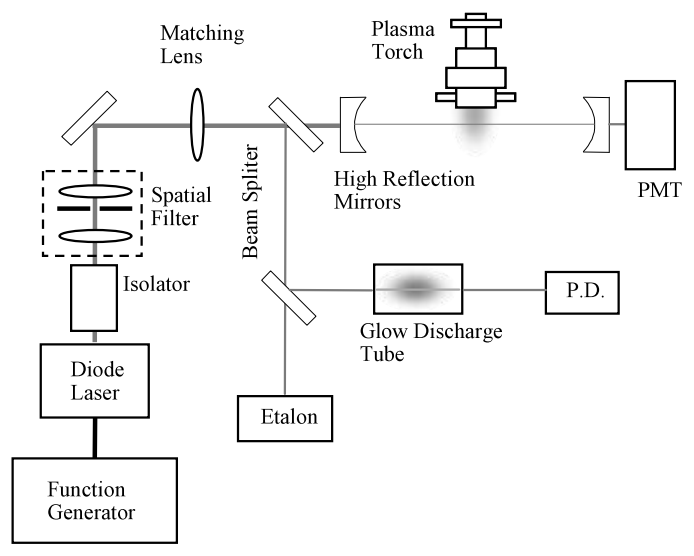

第 2 図 CEAS 計測システムの概略図

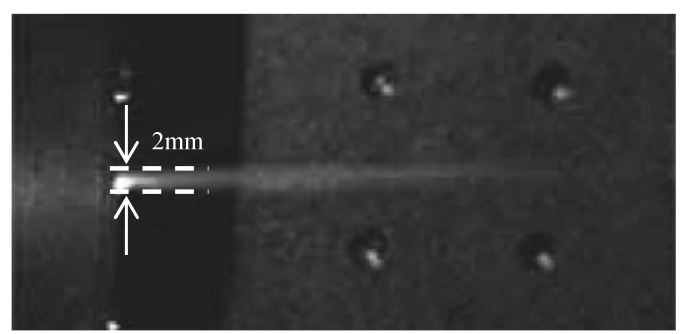

第3図 プラズマトーチアルゴンプルーム写真
グによって理論値よりも大きくなる，乥こで, 共振器中央 部でのレーザー強度分布をビームプロファイラーによって 調べると第 4 図のようになった .この結果から，中央部に おけるビームスポット径は約 $400 \mu \mathrm{m}$ となり,$d=0.6 \mathrm{~m} の$ 共振長においても，空間分解能を $1 \mathrm{~mm}$ 以下にできること が示された .しかし本実験では, プラズマトーチのプルー ムは細く，弚の半径方向分布を計測できるほど空間分解能 は高くないので, プルームを直径 $d_{0}=2 \mathrm{~mm}$ の円柱と近 似して軸方向分布のみを計測した 。

4.2 検出限界 CEAS の検出限界を評価するためには， 吸収準位数密度を何桁も変化させる必要がある. 弚こで本 研究においてはプラズマトーチ気流における $4 \mathrm{~s}^{2}[3 / 2]$ アル ゴン原子の数密度が放射冷却や周辺空気の取り込みによっ て出口からの距離に対して単調に減少することを利用して 検出限界の評価を行った . CEAS の 1 例として第 5 図に代 表的な信号例を示す．また，第 6 図にこのデータから得ら れた吸光度プロファイルと最小 2 乗法によって求められた フォークトフィッティングの結果を示す . 時間軸はエタロン 信号により周波数軸に変換し,アルゴン放電管の参照信号を 用いて吸収中心波長 $(842.46 \mathrm{~nm})$ を求め, 周波数軸の原点 とした . 各位置における $4 \mathrm{~s}^{2}[3 / 2]$ アルゴン原子の数密度を 第 7 図に示す . CEAS における測定誤差は 40 回の掃引のば らつきの標準偏差より求めた .一方, $0.5 \mathrm{~mm}$ から $1.5 \mathrm{~mm}$ においては吸収が大きいため, シングルパス LAS を用い て吸収信号を得ることができた . 測定誤差は 20 回の掃引 のばらつきの標準偏差より求めた . この領域では CEAS に おいては吸収が大きすぎるため適用することができなかっ た .これらの結果から，CEAS を用いることによってシン グルパス LAS と比べて $4 \mathrm{~s}^{2}[3 / 2]$ 準位のアルゴン原子数密 度分布が 3 桁程低い位置においても吸収信号を得ることが できた。

4.3 測定精度 大気圧プラズマトーチにおいては $\Delta \nu_{\mathrm{D}}$ と $\Delta \nu_{\mathrm{L}}$ が同程度であり，1 掃引での CEAS 信号をフォー クトフィッティングして得られた並進温度には, 数密度よ りも大きな偶然誤差があった . 弚こで, 数回の掃引の平均 をとった . 第 8 图に各位置での掃引回数と求められた並進

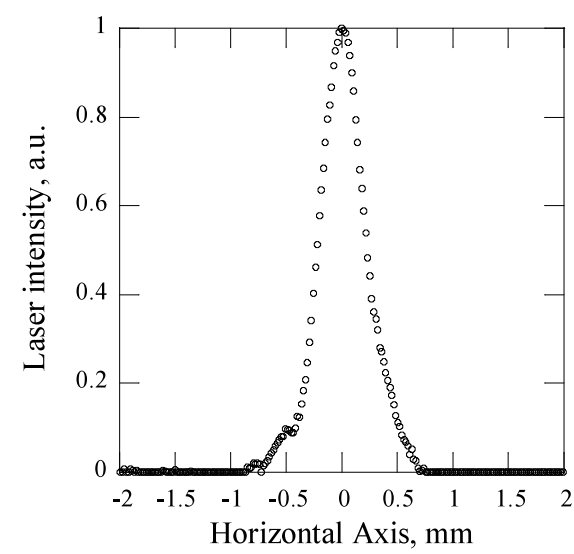

第 4 図 共振器中央部での水平方向におけるレーザー強度分布 


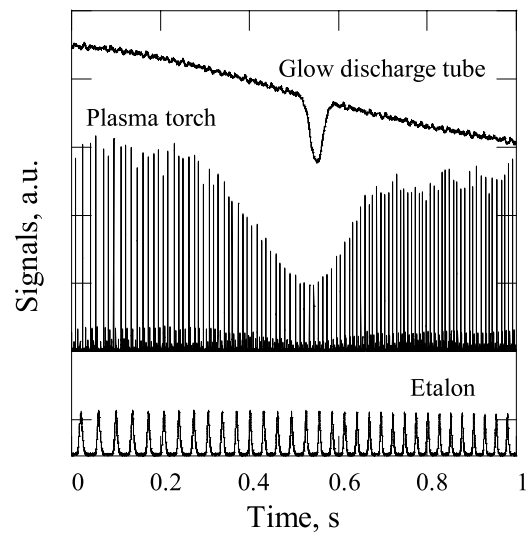

第 5 図 プラズマトーチ出口から $3 \mathrm{~mm}$ における CEAS 信号 , グロー 放電管における LAS 信号とエタロン信号

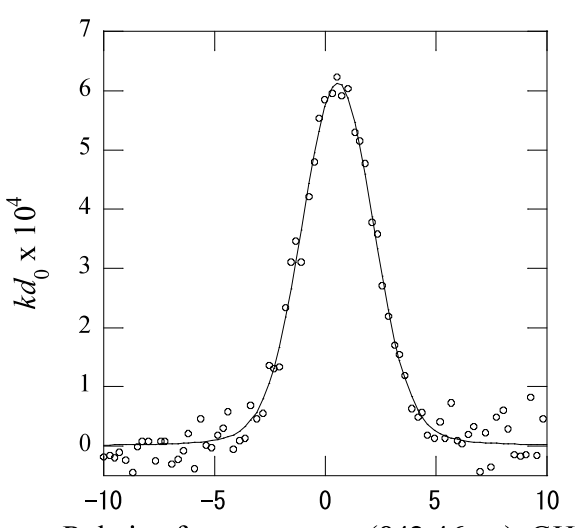

Relative frequency to $v_{0}(842.46 \mathrm{~nm}), \mathrm{GHz}$

第6図 1 掃引の CEAS 信号から求められた吸収プロファイル (O) とフォークトフィッティング, $z=3 \mathrm{~mm}$

温度における偶然誤差の関係を示す . 掃引回数を増やすこ とによって CEAS 法における測定精度を改善できることを 確認した . $2.5 \mathrm{~mm}$ と $3 \mathrm{~mm}$ においては 10 掃引のデータを 平均することによって並進温度における偶然誤差を $5 \%$ 以 下まで低減することができた 。

4.4 測定データ量と測定時間 CEAS においては, 共 振した透過レーザーの鋭い信号波形（第 5 図において櫛型 に見える透過光信号) の最大值を正確に捉えなければなら ないため, サンプリング数を従来の LAS 法に比べて 2 桁 程度大きくする必要がある. 第 9 図に透過光信号の拡大図 を示す . この信号の広がりはレーザー線幅, 共振器の装置 広がりに由来するもので, 半値全幅は $250 \mathrm{kHz}$ 程度である . これを周波数方向に 10 Sample て捉えるとすると, $25 \mathrm{GHz}$ のレーザー周波数掃引には $1 \mathrm{M}$ Sample 必要で, データ平 均を 10 掃引，半径方向に10 ラインの測定を行うと, 1 回 の作動中で $100 \mathrm{M}$ Sample のデータ取得が必要となる. 現 在は $8 \mathrm{M}$ Sample のメモリを有したデジタルオシロスコー プを用いているため，作動中に約十数回のデータ吐き出し 作業が必要となり, 弚れには 15 分程度を要する。しかし最 近は 1 G Sample のメモリを有するデジタルオシロスコー プも市販されているので, これを用いれば吐き出しにかか

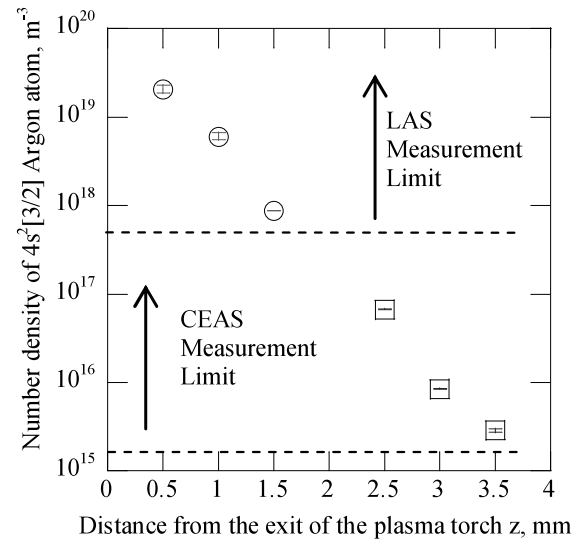

第 7 図 1 掃引において得られた $4 \mathrm{~s}^{2}[3 / 2]$ 準位アルゴン原子数密度 分布

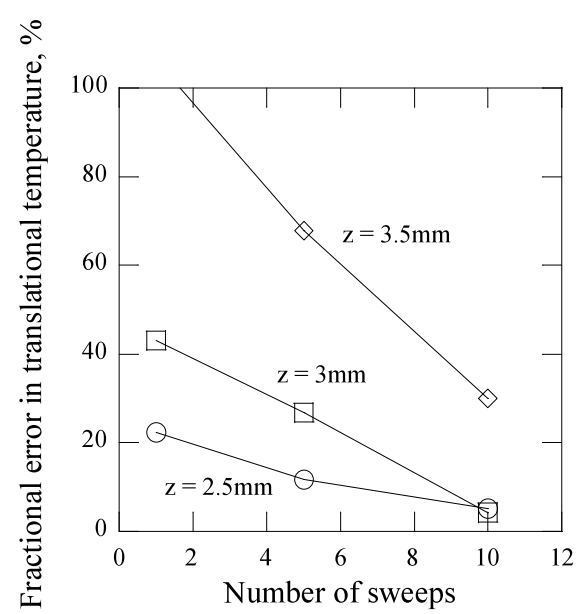

第 8 図 掃引回数と並進温度誤差の関係

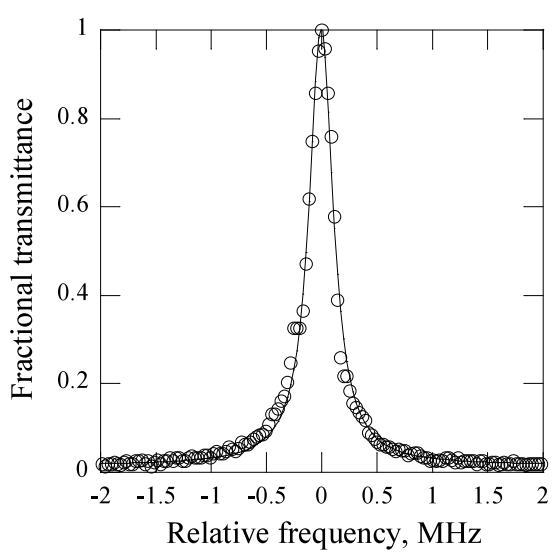

第 9 図 透過光信号の拡大図 : ○がサンプル点を表す

る時間を省くことができ，測定データ量増加による測定時 間の制約は解消されるとともに，掃引回数を増やすことも 容易になるであろう .

4.5 並進温度分布とポピュレーション温度分布 第 10 図に並進温度分布を示す. 距離に対して単調に減少してい ることがわかる $. z=3.5 \mathrm{~mm}$ での誤差が比較的大きいが， 掃引回数を増やして平均すれば精度の高い温度が求まるで 


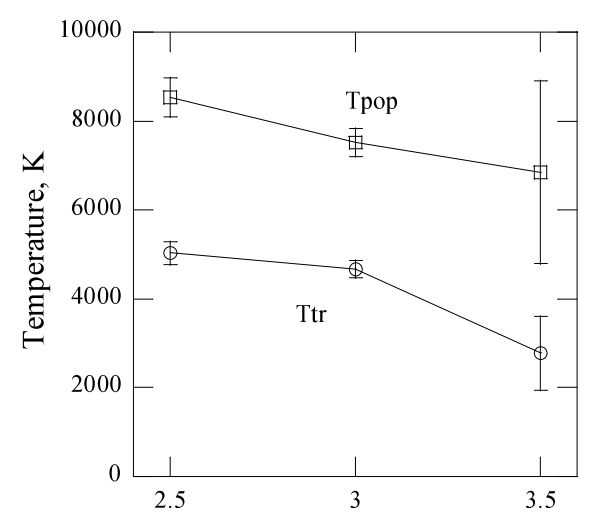

Distance from the exit of the plasma torch, $\mathrm{mm}$

第 10 図 10 掃引の平均で得られた並進温度分布とポピュレーション 温度分布

あろう. 参考として $4 \mathrm{~s}^{2}[3 / 2]$ 準位のポピュレーション温度 分布を示す. ポピュレーション温度の方が $3,000 \mathrm{~K}$ 程度高 くなっており, 電子励起非平衡であることが示唆された . ま た参考として , プラズマトーチプレナム室において熱化学 的に平衡で, 出口まで等エントロピー変化をすると仮定し， プレナム圧と冷却水の温度上昇の測定結果から出口におけ る気流温度を求めると，7,700 K と推定された．

4.6 吸収飽和の影響 一般に CEAS においては共振器 内におけるレーザー強度が高くなるため, 吸収飽和の影響 で温度が高く見積もられている可能性がある . 飽和が起き る目安となる閾値レーザー強度, $I_{\mathrm{S} \_ \text {inhomo }}$ は次式で定義さ れる14).

$$
I_{\text {S_inhomo }}=\frac{2 \pi^{2} h \nu^{3} \Delta \nu_{\mathrm{L}}}{\phi c^{2}}
$$

$\phi$ は次式で表される .

$$
\phi=\frac{A_{j i}}{A_{j i}+Q_{j i}}
$$

ここでは $Q_{j i}=2.5 \times 10^{-9} \mathrm{~s}^{-1}$ とすると ${ }^{15)},(8)$ 式は $I_{\mathrm{S} \text { _inhomo }}, \Delta \nu_{\mathrm{L}}$ それ光れの単位を $\left[\mathrm{W} / \mathrm{mm}^{2}\right],[\mathrm{GHz}]$ とし たとき，次のように表される．

$$
I_{\mathrm{S}_{-} \text {inhomo }}=0.76 \times \Delta \nu_{\mathrm{L}}
$$

ここでは $\Delta \nu_{\mathrm{L}}$ は $3 \mathrm{GHz}$ 程度であったので， $I_{\mathrm{S} \_ \text {inhomo }}$ は $2 \mathrm{~W} / \mathrm{mm}^{2}$ 程度となる . 一方, 共振器内部のレーザー強度 は $10 \mathrm{~mW} / \mathrm{mm}^{2}$ 程度と見積もられるため, 吸収飽和の影 響はほとんどないと考えられる．しかしながら，一般的な プラズマ風洞は減圧環境で作動するため， $I_{\mathrm{S} \_ \text {inhomo }}$ は小さ くなる．关れに応じてレーザー強度を下げる必要があるで あろう .

$$
\text { 5. ま と め }
$$

1) モードマッチングとスペーシャルフィルターを用いて， $0.6 \mathrm{~m}$ の共振長で $1 \mathrm{~mm}$ 以下の空間分解能を得た .
2 ) 反射率 $99.95 \%$ の高反射ミラーを用いることによって， 3 林程度感度が向上し, $10^{15} \mathrm{~m}^{-3}$ 程度の吸収準位数密度の 吸収プロファイルを取ることに成功した．

3) 吸収中心周波数における吸光度が $6 \times 10^{-4}$ 程度のラ インにおいて , 10 掃引のデータを平均することによって並 進温度における偶然誤差を $5 \%$ 以下まで低減できた .

4) プラズマ風洞プルームの 1 断面の分布を計測するの に，25 GHz の周波数掃引幅に対して合計で $100 \mathrm{M}$ Sample のデータ取得が必要であると見積もられた .

5) プラズマトーチのプルームは, 電子励起非平衡状態で あることが示唆された .

\section{参 考 文 献}

1) Auweter-Kurtz, M., Kurtz, H. and Laure, S.: Plasma Generators for Re-Entry Simulation, J. Propul. Power, 12 (1996), pp. 1053-1061.

2) 松井信, 是洞博紀, 小紫公也, 水野雅仁, 葛山 浩, 荒川義博 : アーク風洞プルーム中の原子状酸素数密度分布, 日本航空宇宙学 会論文集，50 (2002), pp. 489-495.

3）松井信 , 小紫公也 , Herdrich, G., Auweter-Kurtz, M. : レーザー 吸収分光法を用いた誘導加熱風洞気流診断，日本航空宇宙学会論 文集，53 (2005)，pp. 379-384.

4) Kim, S., Jeffries, J. B. and Hanson, R. K.: Measurement of Gas Temperature in the Arc-Heater of a Large Scale Arcjet Facility Using Tunable Diode Laser Absorption, 43rd AIAA Aerospace Science Meeting and Exhibit, AIAA Paper 20050900, 2005.

5) O'Keefe, A. and Deacon, D. A. G.: Cavity Ring Down Optical Spectrometer for Absorption Measurements Using Pulsed Laser Sources, Rev. Sci. Instrum., 59 (1988), pp. 2544-2551.

6) Paul, J. B., Lapson, L. and Anderson, J. G.: Ultrasensitive Absorption Spectroscopy with a High-Finesse Optical Cavity and Off-Axis Alignment, Appl. Optics, 40 (2001), pp. 4904-4910.

7) Petry, R., Klee, S., Lock, M., Winnewisser, B. P. and Winnewisser, M.: Spherical Mirror Multipass System for FTIR Jet Spectroscopy Application to the Rovibrationally Resolved Spectrum of Oc5O*, J. Mol. Struct., 612 (2002), pp. 369-381.

8) Barry, H. R., Corner, L., Hancock, G., Peverall, R. and Ritchie, G. A. D.: Cavity-Enhanced Absorption Spectroscopy of Methane at $1.73 \mu \mathrm{m}$, Chem. Phys. Lett., 333 (2001), pp. 285-289.

9) Berden, G., Peeters, R. and Meijer, G.: Cavity-Enhanced Absorption Spectroscopy of the $1.5 \mathrm{~mm}$ Band System of JetCooled Ammonia, Chem. Phys. Lett., 307 (1999), pp. 131138.

10）松崎貴至，石田清道，渡辺泰夫，三保和之，板垣晴昭，芳仲敏成： $750 \mathrm{~kW}$ アーク加熱風洞の構造と動作特性, 航空宇宙技術研究所 資料，TM-76, 2001.

11) Demtroeder, W.: Laser Spectroscopy, 3rd edition, Springer Verlag, Berlin, 2002.

12) Griem, H. R.: Principles of Plasma Spectroscopy, Cambridge University Press, Cambridge, 2005.

13) Davis, C. C.: Lasers and Electro-Optics, Cambridge University Press, Cambridge, 1996.

14) Matsui, M., Komurasaki, K., Ogawa, S. and Arakawa, Y.: Influence of Laser Intensity on Absorption Line Broadening in Laser Absorption Spectroscopy, J. Appl. Phys., 100 (2006), 063102.

15) Baer, D. S., Chang, H. A. and Hanson, R. K.: Semiconductor Laser Absorption Diagnostics of Atomic Oxygen in an Atmospheric-Pressure Plasma, J. Quant. Spectrosc. Radiat. Transfer, 50 (1993), pp. 621-633. 